Dear Author,

Please, note that changes made to the HTML content will be added to the article before publication, but are not reflected in this PDF.

Note also that this file should not be used for submitting corrections. 


\title{
Q1 Temporal dynamics of suspended sediment transport in a glacierized Andean basin
}

\author{
Q2 Luca Mao *, Ricardo Carrillo \\ Pontificia Universidad Católica de Chile, Department of Ecosystems and Environments, Santiago, Chile
}

\section{A R T I C L E I N F O}

\section{Article history:}

Received 19 August 2015

Received in revised form 29 January 2016

Accepted 3 February 2016

Available online $\mathrm{xxxx}$

\section{Keywords:}

Suspended sediment transport

Hysteresis

Glacier melting

Chile

\begin{abstract}
A B S T R A C T
Suspended sediment transport can affect water quality and aquatic ecosystems, and its quantification is of the 12 highest importance for river and watershed management. Suspended sediment concentration (SSC) and dis- 13 charge were measured at two locations in the Estero Morales, a Chilean Andean stream draining a small basin 14 $\left(27 \mathrm{~km}^{2}\right)$ hosting glacierized areas of about $1.8 \mathrm{~km}^{2}$. Approximately half of the suspended sediment yield 15 ( 470 t year $^{-1} \mathrm{~km}^{-2}$ ) was transported during the snowmelt period and half during glacier melting. The hysteresis 16 patterns between discharge and SSC were calculated for each daily hydrograph and were analysed to shed light 17 on the location and activity of different sediment sources at the basin scale. During snowmelt, an unlimited sup- 18 ply of fine sediments is provided in the lower and middle part of the basin and hysteresis patterns tend to be 19 clockwise as the peaks in SSC precede the peak of discharge in daily hydrographs. Instead, during glacier melting 20 the source of fine sediments is the proglacial area, producing counterclockwise hysteresis. It is suggested that the 21 analysis of hysteretic patterns over time provides a simple concept for interpreting variability of location and ac- 22 tivity of sediment sources at the basin scale.

(C) 2015 Published by Elsevier B.V. 24

\section{Introduction}

The quantification of suspended sediment transport in river systems is of the highest importance for ecologists and for land- and water-use managers. Sediments in suspension convey nutrient and contaminant loading that can affect aquatic ecosystems (e.g. Wood and Armitage, 1999; Bilotta and Brazier, 2008) and water quality for human consumption (e.g. Ryan, 1991). Also, fine sediments can infiltrate gravel affecting fish and macroinvertebrates (e.g. Wilber and Clarke, 2001; Blettler et al., 2015) and increasing coarse sediment transport (Curran and Wilcock, 2005). Fine sediments transported in suspension can be recruited from the river network (bed and bank erosion) or can be sourced by the basin, especially due to soil erosion, gully erosion, and mass failure such as landslides or debris flows. Beside the natural sources of fine sediments, human activities such as overgrazing, agriculture, forest and mining operations, and urbanization can remarkably increase the availability of sediments (e.g. Owens et al., 2005). Sediment sources can be investigated using radionuclides as fingerprinting techniques (Haddadchi et al., 2013) which permit the quantification of the relative contributions of various sources to the total yield (e.g. Walling et al., 2006; Collins et al., 2013). Also, the source of fine sediments transported in suspension may be explored by measuring the colour of sediments using diffuse reflectance spectrometry (Martínez-Carreras et al., 2010), the geochemical properties of sediments (Motha et al., 2003), or the size of sediments (Walling and Amos, 1999; Davis and Fox,

* Corresponding author at: Department of Ecosystems and Environments, Pontificia Universidad Católica de Chile, Av. Vicuña Mackenna 4860, Macul, Santiago, Chile.

E-mail address: Imao@uc.cl (L. Mao).
2009). Alternatively, sources and degree of activity of sediment sources 58 can be inferred by analysing the changes in the suspended sediment 59 concentration (SSC) with respect to the changes in liquid discharge 60 (Q) at the scale of a single event. If the SSC-Q relationship is scattered 61 and non-unique, hysteretic loops can often be detected and classified 62 as clockwise (when the peak of SSC peak occurs before the peak of 63 Q) or counterclockwise loop (opposite behaviour) (e.g. Williams, 64 1989; Lenzi and Marchi, 2000; Gao and Josefson, 2012; Yeshaneh 65 et al., 2013).

Clockwise hysteresis has been attributed to unlimited sediment 67 supply. At the scale of the single flood event, clockwise hysteresis can 68 be due to early exhaustion of sediment sources, nearby sources of sedi- 69 ments, and sediment being provided by the channel bed rather than the 70 slopes (e.g. Asselman, 1999; Rovira and Batalla, 2006; Gao and 71 Pasternack, 2007). Conversely, counterclockwise hysteresis may be 72 due to the fact that the sediment source is far from the point of monitor- 73 ing (Klein, 1984), bank failures which tend to occur after the peak of the 74 flood when the bank is saturated (Rinaldi et al., 2004), and sediment de- 75 pletion in the channel system (Walling and Webb, 1982). In an attempt 76 to explore quantitatively the degree of the hysteretic loops, Aich et al. 77 (2014) proposed a dimensionless metric for an hysteresis index that is 78 provided by the size of the loop and its direction. By using normalized 79 values of SSC and Q, the resulting index is comparable between events 80 and sites, improving previously proposed indices (e.g. Langlois et al., 81 2005; Lawler et al., 2006).

Apart from the evaluation of sediment availability at the scale of a 83 single flood event, hysteresis has been used to explore sediment dy- 84 namics over longer terms. Analysing the dynamics of suspended sedi- 85 ment in the Rhine River, Asselman (1999) reported a decrease of 86 
sediment concentration from winter to spring and a dominance of clockwise hysteresis during early floods, and related this to a progressive sediment depletion during a hydrological year. This depletion effect through time was also found by analysing hysteretic patterns of single floods in a $300 \mathrm{~km}^{2}$ basin of central New York (Gao and Josefson, 2012). They reported that clockwise loops are more frequent during snowmelt, due to the ready-availability of in-channel fine sediments, and to the fact that higher elevations covered by snow do not contribute to sediment generation. Analysing rainfall-generated floods on three small basins in Mexico, Duvert et al. (2010) also reported strong seasonality in suspended sediment transport, due to the filling and depletion of in-channel sediment storage, and connectivity of sediment sources at the basin scale. Fan et al. (2013) explicitly mention a "store-release" set of processes at the seasonal scale, stating that sediments are being prepared in winter and spring (when counterclockwise hysteresis are more common), and exported in rainy seasons.

In basins dominated by snowmelt, evidence from the literature is similar, and the relationship between hysteresis and sediment sources is even more closely related to seasonality. For example, Iida et al. (2012) showed that early snowmelt events featured clockwise hysteresis due to the flushing of sediments stored on the channel bed, whereas during the late snowmelt season, counterclockwise loops were more common due to the dominance of sediment sources at the basin scale. On glacierized basins, hysteresis loops can be observed every day due to the typical diurnal variation of discharge and suspended sediments, but field evidence is scarce. Singh et al. (2005) analysed daily fluctuations of discharge due to the ablation of a large Himalayan glacier reporting clockwise hysteresis for all the ablation season. On the other hand, Wulf et al. (2012) showed that in the western Himalaya more suspended sediment is transported during late summer than during the onset of the monsoon season, implying that transiently stored material is not mobilized with the first flood events. However, Stott et al. (2014) registered both clockwise and anticlockwise hysteresis in small glacierized basins in south-west Greenland. Despite this growing body of research on suspended sediment dynamics in glacierized basins, virtually no evidence is available from the Southern Andean Range, where glaciers are shrinking (Rivera et al., 2000; Masiokas et al., 2009; Pellicciotti et al., 2014) and water supplied by glacier-melting is crucial for agriculture, hydropower generation, and drinking water supplies. In this paper we aim to explore the temporal dynamics of SSC in a small glacierized basin in the southern Andes. Suspended sediment concentration and yield, and hysteresis associated with daily fluctuations of discharges during the snow and glacier melt periods of two seasons are used to illustrate changes and dynamics of sediment availability at the basin scale.

\section{Materials and methods}

The study has been carried out in the Estero Morales, a high-gradient stream of the Southern Andes located in the Chilean Metropolitan Region, approximately $100 \mathrm{~km}$ southeast from Santiago (Fig. 1). The basin ranges from 1850 to $3815 \mathrm{~m}$ a.s.l., and extends for $27 \mathrm{~km}^{2}$. It drains into the Maipo basin, which eventually flows to the Pacific Ocean. In its upper part (at elevations higher than $2690 \mathrm{~m}$ a.s.l.), the basin hosts glacierized areas, some uncovered and some covered by debris (Fig. 2). The biggest portion of the glacier is called San Francisco, and overall the glacierized area has a current extent of $1.8 \mathrm{~km}^{2}$ (Fig. 1). Although glaciological studies on this basin are still not available, recent evidence from the surrounding area shows that glaciers are retreating at a considerable rate. For example, the Juncal Sur glacier in the upper part of the Río Maipo basin has retreated approximately $50 \mathrm{~m}_{\text {year }}{ }^{-1}$ and has thinned at a rate of $1 \mathrm{~m}^{\text {year }}{ }^{-1}$ from 1955 to 1997 (Rivera et al., 2000; Masiokas et al., 2009). The mean annual rainfall measured in the nearest station (Embalse El Yeso station, installed at $2475 \mathrm{~m}$ a.s.l.) is around $574 \mathrm{~mm}$, and precipitation occurs mainly as snowfall from May to September (approximately $82 \%$ of total

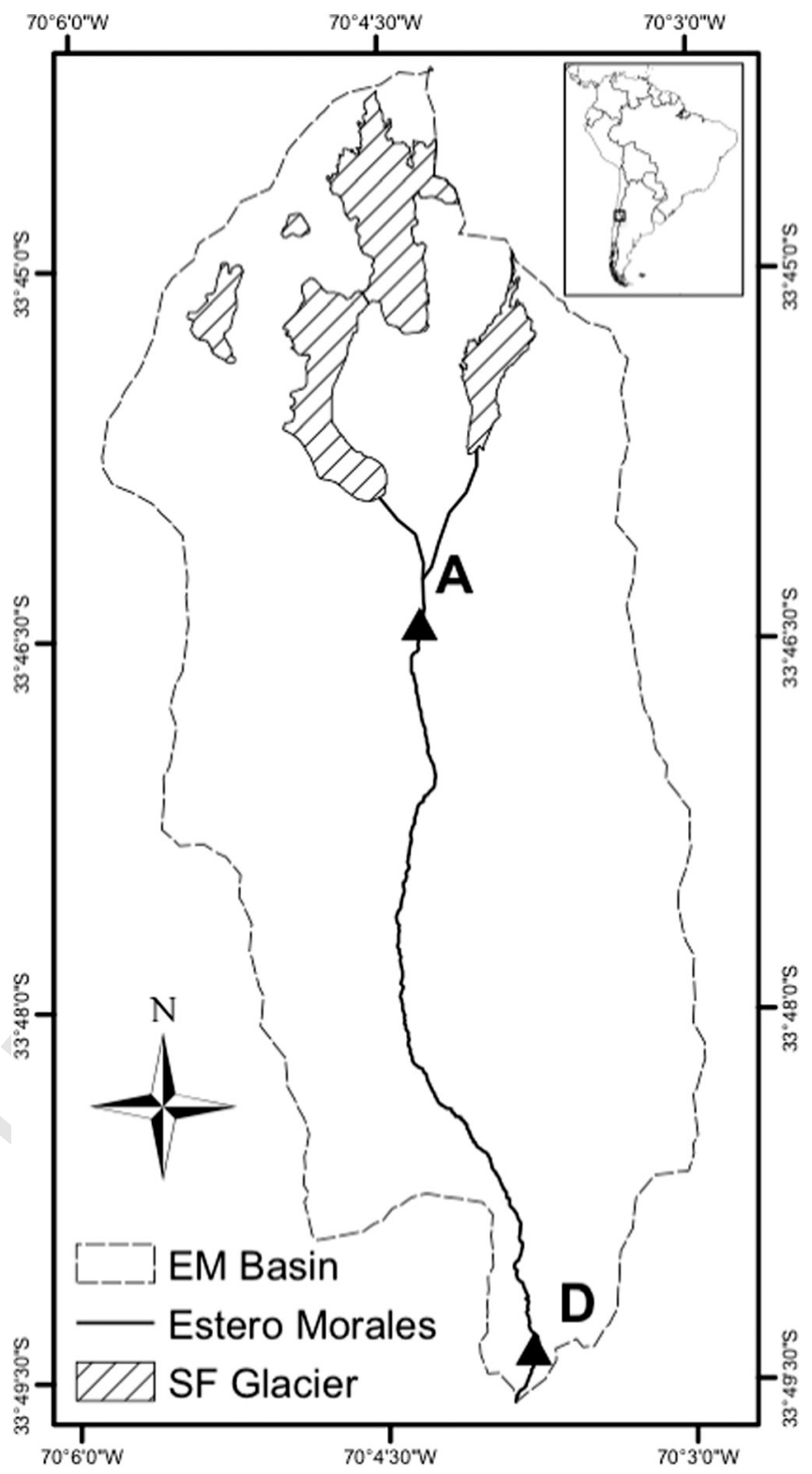

Fig. 1. Map of the Estero Morales, showing the location of the monitoring sites D and A.

precipitation), with occasional summer convective storms. Runoff 151 is dominated by snowmelt in late spring (from late September to 152 November), and glacier melt from December to March, providing a 153 long season of daily fluctuations of discharge (Fig. 3). 154

The solid geology of the basin consists of limestones and conglomer- 155 ate breccias, with some volcanic formations on the eastern slopes 156 (Infante Fabres, 2009). Fluvial and glacial Quaternary deposits are very 157 common, and alluvial fans, moraine deposits and talus slopes are wide- 158 spread features of the landscape (Fig. 2). When present, soils are very 159 thin and covered by montane grassland with dispersed shrubs dominat- 160 ed by Chuquiraga oppositifolia and Molinum spinosum. The average slope 161 of the main channel is about $0.105 \mathrm{~m} \mathrm{~m}^{-1}$. However, three segments 162 with different morphology could be recognised. From the glacier to the 163 end of a moraine that confined the channel down to $2442 \mathrm{~m}$ a.s.l., the 164 channel is steep $\left(0.15 \mathrm{~m} \mathrm{~m}^{-1}\right)$ and featuring cascade and step-pool 165 reaches (sensu Montgomery and Buffington, 1997). From 2442 to 166 $2238 \mathrm{~m}$ a.s.l. the stream flows in the relatively large U-shape "hanging" 167 valley with riffle-pool morphology, with large coarse bars and multiple 168 channels on some reaches (Fig. 2). From 2238 m a.s.l. to the confluence 169 

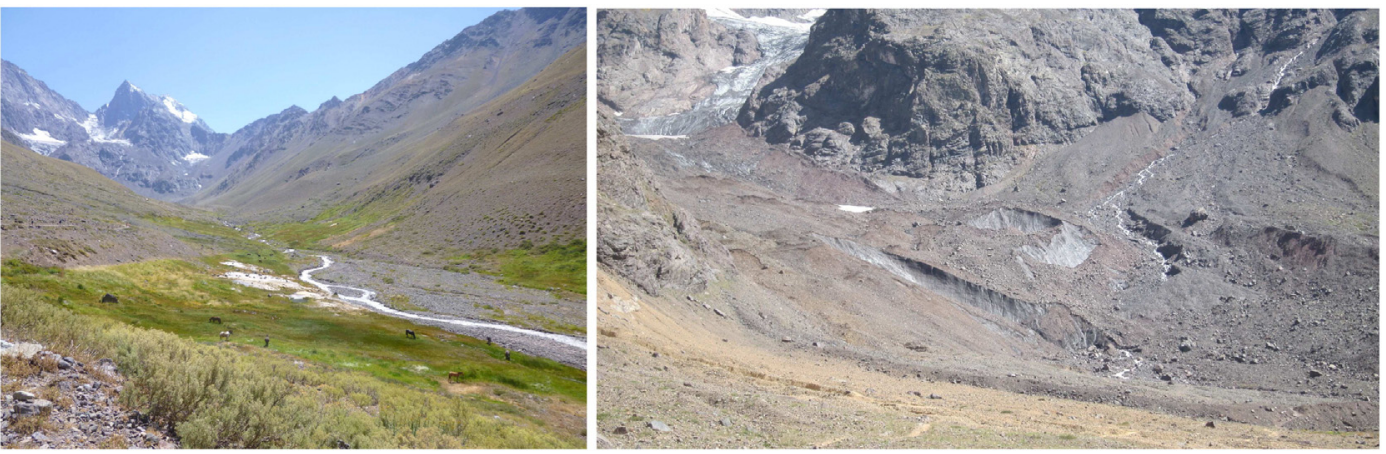

Fig. 2. Upstream view of the Estero Morales valley (on the left) and view of the lower portion of the glacierized area (on the right).

with the El Volcan River, the river cuts into glacier deposits. In this lower portion which is very confined and steep $\left(0.14 \mathrm{~m} \mathrm{~m}^{-1}\right)$, the stream is characterized by coarse sediments and a cascade/step-pool morphology.

Two monitoring sites were established on the Estero Morales (Fig. 1), namely D near the confluence with El Volcan River (drainage area $26.70 \mathrm{~km}^{2} ; 6.96 \%$ of the basin covered by glacierized areas, $26 \mathrm{~km}^{2} 7.15 \%$ at D), and A (drainage area $10.92 \mathrm{~km}^{2} ; 17.03 \%$ of the basin covered by glacierized areas). In July 2013, a multiparameter water quality sonde (OTT Hydrolab MS5) was installed on D, measuring $\mathrm{pH}$, water temperature, electrical conductivity and turbidity within a range from 0 to $3000 \mathrm{NTU}$ ( $\pm 1 \%$ up to $100 \mathrm{NTU}$; $\pm 3 \%$ from 100 to $400 \mathrm{NTU} ; \pm 5 \%$ from 400 to $3000 \mathrm{NTU}$ ). Water stage was monitored in $\mathrm{D}$ using a pressure transducer sensor in a cross-section confined by the presence of a bridge. Turbidity and water stage were monitored at the instrumented cross-section D at $1 \mathrm{~h}$ resolution until October 2014 and then at 10 min resolution from October 2014 to April 2015. Rainfall was measured in D every 5 min by a non-heated tipping-bucket rain gauge. A natural cross-section located at A (see Fig. 1) was instrumented in February 2014 with similar equipment previously installed in D, in order to monitor water stage, temperature, conductivity and turbidity at 10 minute resolution.

Stage-discharge rating curves were established for both D and A based on 32 and 18 discharge measurements, respectively. Discharge was measured using the salt dilution method (Moore, 2005) for a range of field conditions ranging from 0.11 to $2.56 \mathrm{~m}^{3} \mathrm{~s}^{-1}$.

In order to establish an empirical relationship between NTU and the concentration of sediments in suspension (SSC, in $\mathrm{mg} \mathrm{l}^{-1}$ ), water samples were collected using a USGS DH-48 handheld depth integrated water sampler. Samples were collected only randomly in D during the 2013-2014 season. Conversely, from December 2014 to March 2015, samples were collected once a month at 3 hourly spaced intervals during $24 \mathrm{~h}$, in order to take samples during a wide range of discharges 201 $\left(0.8-2.3 \mathrm{~m}^{3} \mathrm{~s}^{-1}\right)$ and NTU (8-2424). Overall, 55 and 36 samples were 202 collected in D and A, respectively. The collected samples were filtered 203 in order to assess the concentration of suspended sediments in $\mathrm{g} \mathrm{l}^{-1} .204$ The power-law empirical regressions between NTU and SSC for both D 205 and A sites were fitted with coefficients of determination of 0.874 and 206 0.862 , respectively.

At the daily scale, fluctuations of discharge and associated suspended 208 sediment transport exhibited a certain degree of hysteresis, which was 209 quantitatively assessed using metrics recently proposed in literature 210 (Langlois et al., 2005; Lawler et al., 2006; Aich et al., 2014). The hysteresis 211 index $(\mathrm{H})$ proposed by Langlois et al. (2005) relates the area under the 212 Q-SSC curves obtained for the rising and falling limb of hydrographs. 213 Hysteresis is classified as clockwise when $\mathrm{H}>1$ (SSC peaks before Q), 214 and counterclockwise when $\mathrm{H}<1$ (SSC peaks after Q). Lawler et al. 215 (2006) developed a dimensionless hysteresis index ( $\mathrm{MI}_{\mathrm{mid}}$ ) that is calcu- 216 lated comparing the value of SSC measured during the rising and the fall- 217 ing limb of the hydrograph at a discharge $\left(\mathrm{Q}_{\text {mid }}\right)$ calculated as the 218 average between the minimum and maximum discharge of the daily 219 fluctuation. When the SSC is higher in the rising limb of the hydrograph 220 (indicating clockwise hysteresis), the $\mathrm{HI}_{\text {mid }}$ is higher than 0 . On the other 221 hand, $\mathrm{HI}_{\text {mid }}<0$ indicates a counterclockwise hysteresis. Also, the higher 222 the deviation from 0 , the greater the hysteretic loop. Because the value of 223 this index depends on the absolute values of measured variables (SSC 224 and Q), Aich et al. (2014) proposed the use of normalized discharge 225 and SSC (values then range from 0 to 1 ). Rising and falling limbs of the 226 hydrograph are separated by a line starting at the $Q_{\max }$ and ending at 227 the last value of the temporal series. Then, the distance from this line 228 to the farther value of SSC on the rising and falling limb are calculated 229 and totalled. The calculated hysteresis index (HI) is positive if the loop 230 is clockwise, and negative if the loop is counterclockwise.
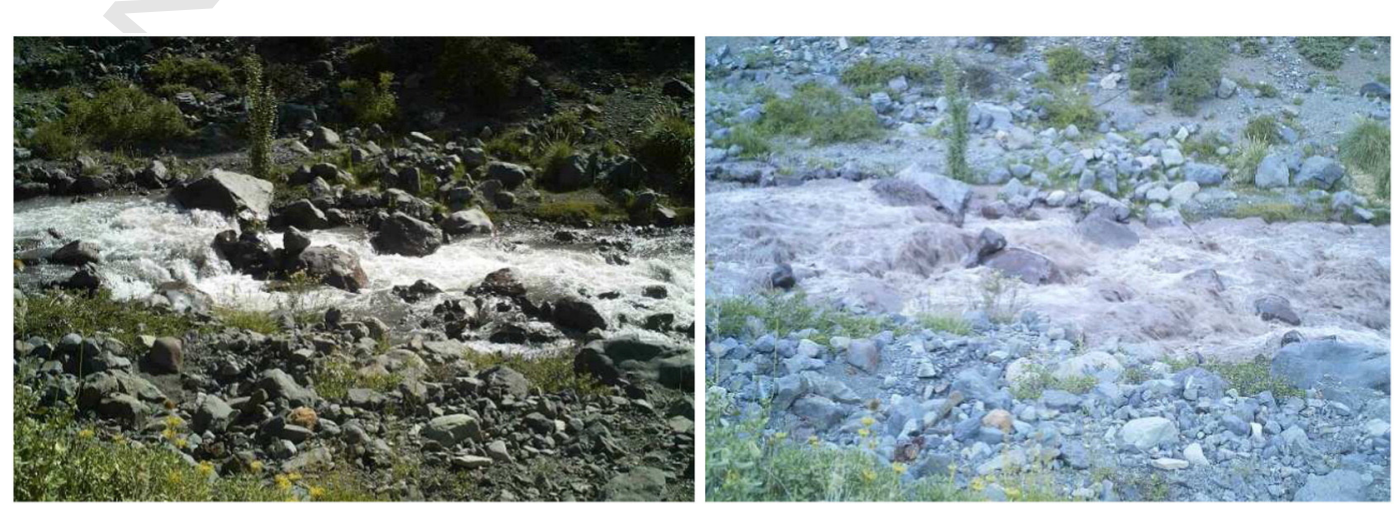

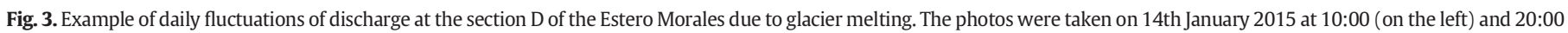
(on the right). 


\section{Results}

\subsection{Relationships between discharge and suspended} sediment concentration

Relationships between paired measurements of liquid discharge and suspended sediment concentration have been obtained as in similar studies. Fig. 4 shows an example of the very wide scatter that exists in the relationship between the two variables. For instance, at a discharge of $2 \mathrm{~m}^{3} \mathrm{~s}^{-1}$, in the monitoring site D suspended sediment concentrations ranging from 63 to $903 \mathrm{mg} \mathrm{l}^{-1}$ were registered during the 20132014 season. Besides, a concentration of $400 \mathrm{mg} \mathrm{l}^{-1}$ was registered during flow conditions ranging from 1.6 to $3.4 \mathrm{~m}^{3} \mathrm{~s}^{-1}$ (Fig. 4). Due to this very wide scatter in the data, the coefficient of determination of a power law regression is very poor $\left(R^{2}=0.343\right.$ for $D$ in $2013-2014$; $R^{2}=0.306$ for $D$ in $2014-2015 ; R^{2}=0.465$ for $A$ in $\left.2014-2015\right)$. The coefficients of determination of the regressions between Q and SSC increase substantially if data are analysed at the monthly scale. Table 1 shows that the correlations between SSC and Q are weaker for the first months of the snowmelt season, and are generally stronger when glacier melt becomes the most important source of water discharge (i.e. from December). Also, Fig. 4 shows that regression lines plot differently depending on the months from which they are derived, shifting towards the right as the summer season progresses, suggesting that sediments are progressively less available from spring to summer season. For example, for transporting $200 \mathrm{mg} \mathrm{l}^{-1}$ of sediments in suspension, $1.27 \mathrm{~m}^{3} \mathrm{~s}^{-1}$ is needed in October 2013, $1.69 \mathrm{~m}^{3} \mathrm{~s}^{-1}$ in December 2013 , and up to $2.68 \mathrm{~m}^{3} \mathrm{~s}^{-1}$ in February 2014. A F-test ( $\mathrm{p}<0.05$ ) conducted on Q and SSC data collected in 2013-2014 in D (Fig. 4) shows that October is statistically different than November ( $\mathrm{p}$-value $=$ $1.4 \mathrm{E}-8)$ and that December is significantly different than January ( $\mathrm{p}$ value $=0.0012$ ), whereas for the other paired months the $\mathrm{p}$-value is always higher than 0.3 . This suggests that suspended sediment transport generated by diverse runoff-generating processes is significantly different. In fact, the data collected from January to March, characterized by pure glacier melting, are not significantly different. Very similar results are available for data collected in 2014-2015.

\subsection{Suspended sediment yield (SSY)}

Paired values of discharge and suspended sediment concentration were used to calculate SSY at the monthly scale for the two study years. Because no suspended sediment could be measured at significant concentration after March and before October, sediment yield is virtually limited to 6 months. Fig. 5 shows that suspended sediment yield in
October and November ranges from 50 to $70 \mathrm{t}$ per month per $\mathrm{km}^{2}$ in 273 the monitoring site D. Runoff in October and November is mostly due 274 to snowmelt as rainfall is very unusual and a significant percentage of 275 the basin is still covered by snow. Fig. 5 shows the percentage of the 276 basin covered by snow at the end of each month, as calculated using sat- 277 ellite images. At the beginning of October 2013 and 2014, nearly $80 \%$ of 278 the basin upstream of the monitoring site D was covered by snow, and 279 this percentage reduced to approximately $50 \%$ by the end of October, 280 and then $20 \%$ by the end of November. December therefore is a month 281 in which glacier melting becomes important as a source of runoff gener- 282 ation, and by the middle of December virtually all liquid discharges are 283 produced by the glacier melting. Sediment yield during the central sum- 284 mer months (December and January) is higher than $50 \mathrm{t}$ per month per 285 $\mathrm{km}^{2}$ in D, and during the 2013-2014 monitoring period was even higher 286 than $100 \mathrm{t}$ per month per $\mathrm{km}^{2}$. After that, suspended sediment yield re- 287 duces to approximately $50 \mathrm{t}$ per month per $\mathrm{km}^{2}$ in February and March. 288 The dynamics of sediment yield over time is relatively similar for the 289 two monitoring seasons at site D, even if sediment yield is higher in 290 summertime in 2013-2014, possibly due to different availability of sed- 291 iments at the basin scale, which could not be assessed in this study. In- 292 formation from monitoring site A is more scattered and difficult to 293 interpret as no data are available for January 2014-2015 (Fig. 5). How- 294 ever, the amount of transported fine sediments appears higher than in 295 $\mathrm{D}$, and sediment yield in late summer time was lower than in November 296 and December as in D. The overall amount of sediments transported in 297 suspension out of the basin at site $\mathrm{D}$ is approximately 470 tyear $^{-1} \mathrm{~km}^{-2}, 298$ $51 \%$ of which was due to snowmelt, $47 \%$ due to glacier melting, and ap- 299 proximately only $2 \%$ due to rainfall events. This figure is relatively sim- 300 ilar if calculated for monitoring site A, being the fine sediment yield of 301 $430 \mathrm{t}^{\text {year }}{ }^{-1} \mathrm{~km}^{-2}$, and the percentage of it occurring in snowmelt, 302 glacier melting, and rainfall events being around 57, 41, and 2\%, 303 respectively.

\subsection{Hysteresis of suspended sediment transport}

305

Daily fluctuations of discharge due to snow and glacier melting show 306 some degree of hysteresis with the concentration of suspended sedi- 307 ments. Fig. 6 shows two daily hydrographs which occurred in December 308 2013 and January 2104, which were similar in terms of duration and 309 magnitude, but featured two different hysteresis patterns. In fact, 310 every daily hydrograph features some degree of hysteresis, which was 311 quantified using the three indices (Langlois et al., 2005; Lawler et al., 312 2006; Aich et al., 2014). Because each index is calculated taking into ac- 313 count different characteristics of the rising and falling limbs of $Q$ and 314 SSC, they can provide different values for the same event, and are not 315

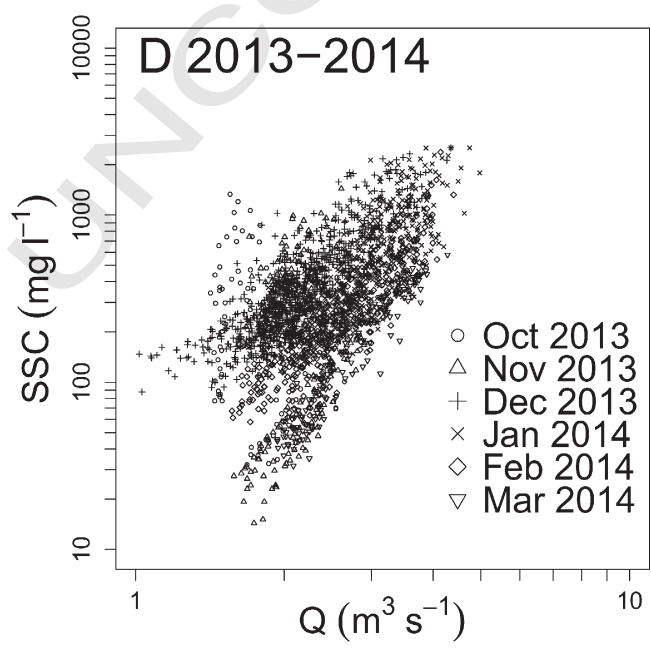

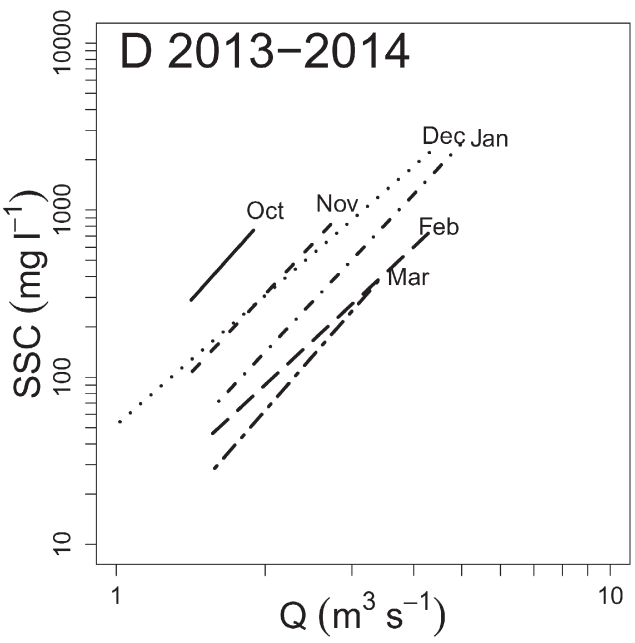

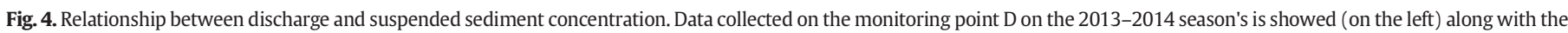
best-fit power-law regressions (on the right), which are reported on Table 1. 
Table 1

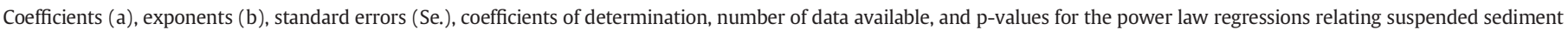
transport $\left(\mathrm{mg} \mathrm{l}^{-1}\right)$ and liquid discharge $\left(\mathrm{m}^{3} \mathrm{~s}^{-1}\right)$ for data collected on spring and summer months of the two seasons (2013-2014 and 2014-2015).

\begin{tabular}{|c|c|c|c|c|c|c|c|c|c|}
\hline Season & Site & Month & $\mathrm{a}$ & $\mathrm{b}$ & Se. a & Se. b & $\mathrm{n}$ & $\mathrm{R}^{2}$ & $\mathrm{p}$ \\
\hline \multirow[t]{6}{*}{ 2013-2014 } & \multirow[t]{6}{*}{$\mathrm{D}$} & Oct & 1.171 & 6.827 & 0.282 & 1.456 & 49 & 0.319 & $2.39 \mathrm{E}-05$ \\
\hline & & Nov & 1.567 & 2.976 & 0.069 & 0.231 & 273 & 0.380 & $<2.2 \mathrm{E}-16$ \\
\hline & & Dec & 1.878 & 2.076 & 0.020 & 0.056 & 744 & 0.651 & $<2.2 \mathrm{E}-16$ \\
\hline & & Jan & 1.300 & 2.841 & 0.033 & 0.073 & 689 & 0.688 & $<2.2 \mathrm{E}-16$ \\
\hline & & Feb & 1.152 & 2.611 & 0.043 & 0.105 & 308 & 0.669 & $<2.2 \mathrm{E}-16$ \\
\hline & & Mar & 0.528 & 3.906 & 0.071 & 0.205 & 159 & 0.698 & $<2.2 \mathrm{E}-16$ \\
\hline \multirow{11}{*}{ 2014-2015 } & \multirow[t]{6}{*}{$\mathrm{D}$} & Oct & 0.718 & 4.543 & 0.090 & 0.226 & 739 & 0.353 & $<2.2 \mathrm{E}-16$ \\
\hline & & Nov & 0.619 & 4.241 & 0.033 & 0.079 & 3219 & 0.472 & $<2.2 \mathrm{E}-16$ \\
\hline & & Dec & 1.492 & 3.187 & 0.017 & 0.052 & 3209 & 0.541 & $<2.2 \mathrm{E}-16$ \\
\hline & & Jan & 1.624 & 3.172 & 0.019 & 0.061 & 2737 & 0.496 & $<2.2 \mathrm{E}-16$ \\
\hline & & Feb & 0.343 & 6.017 & 0.026 & 0.084 & 3484 & 0.595 & $<2.2 \mathrm{E}-16$ \\
\hline & & Mar & 0.264 & 6.597 & 0.030 & 0.105 & 3529 & 0.527 & $<2.2 \mathrm{E}-16$ \\
\hline & \multirow[t]{5}{*}{ A } & Oct & & & & & & & \\
\hline & & Nov & 1.834 & 2.667 & 0.023 & 0.085 & 1800 & 0.353 & $<2.2 \mathrm{E}-16$ \\
\hline & & Dec & 2.441 & 0.883 & 0.006 & 0.038 & 2719 & 0.167 & $<2.2 \mathrm{E}-16$ \\
\hline & & Jan & 2.006 & 3.438 & 0.008 & 0.059 & 1903 & 0.642 & $<2.2 \mathrm{E}-16$ \\
\hline & & $\begin{array}{l}\text { Feb } \\
\text { Mar }\end{array}$ & 2.316 & 2.573 & 0.004 & 0.025 & 3475 & 0.752 & $<2.2 \mathrm{E}-16$ \\
\hline
\end{tabular}

directly comparable among them. For instance, the flood that occurred on the 26th-27th December 2013 featured clockwise hysteresis, which was quantified as $0.28,1.96$, and 0.53 using the Aich et al. (2014); Langlois et al. (2005), and the Lawler et al. (2006) approaches, respectively (Fig. 6). Being the only parameter calculated on normalized values of Q and SSC, the recent Aich's HI index is the only one which can be used to assess the absolute degree of hysteresis, as values can range from -1.41 to 1.41 . Following Aich's HI index, the 26th-27th December 2013 would therefore result being only slightly clockwise (Fig. 6).

Fig. 7 shows the range of hysteresis indices obtained for each daily hydrograph, grouped at the monthly scale for the sake of clarity as for the relationships between discharge and suspended sediment concentration. Although these indices measure hysteresis in different ways, some general trends are recognisable. Overall, in monitoring site D, hydrographs of the very early snow melt (October) tend to feature very limited hysteresis, thus suggesting that the relationship between $\mathrm{Q}$ and SSC at the flood scale tend to be less scattered. As the snowmelt season progresses, the hysteresis at the flood scale tend to become clockwise, suggesting that the sources of fine sediments are readyavailable. Hysteresis tend to be clockwise in November for both monitoring years, but also in December in 2014-2015 probably due to higher snow accumulation during the winter time. Next, when glacier melt becomes the dominant source of runoff, hysteresis tends to be preferen- 338 tially counterclockwise, as all indices become progressively lower. By 339 February, when daily fluctuations of discharge due to glacier melt are 340 smoother and the magnitude of flood peaks reduces, hysteresis is pre- 341 dominantly counterclockwise, thus suggesting limited sediment supply 342 conditions. At the very end of the glacier melt period, all indices tend to 343 increase. This could be related to the occurrence of floods generated by 344 rainfall events, which tend to happen in March, before precipitation will 345 occur as snowfall from April.

Evidence of hysteresis for glacier melt events registered in A is less 347 straightforward to read because of the lack of data in January 2015, 348 but a tendency for hysteresis to be progressively clockwise at the begin- 349 ning of the melt season and then progressively counterclockwise to- 350 wards the end of the season is evident (Fig. 7).

351

\subsection{Celerity of discharge and suspended sediment concentration along the 352 main channel

Because discharge and suspended sediment concentration were 354 measured in both A and D at the same time in 2014-2015, daily fluctu- 355 ations of these two variables can be compared in order to assess the 356 celerity of Q and SSC from A to D. Since multiple or asymmetric peaks 357
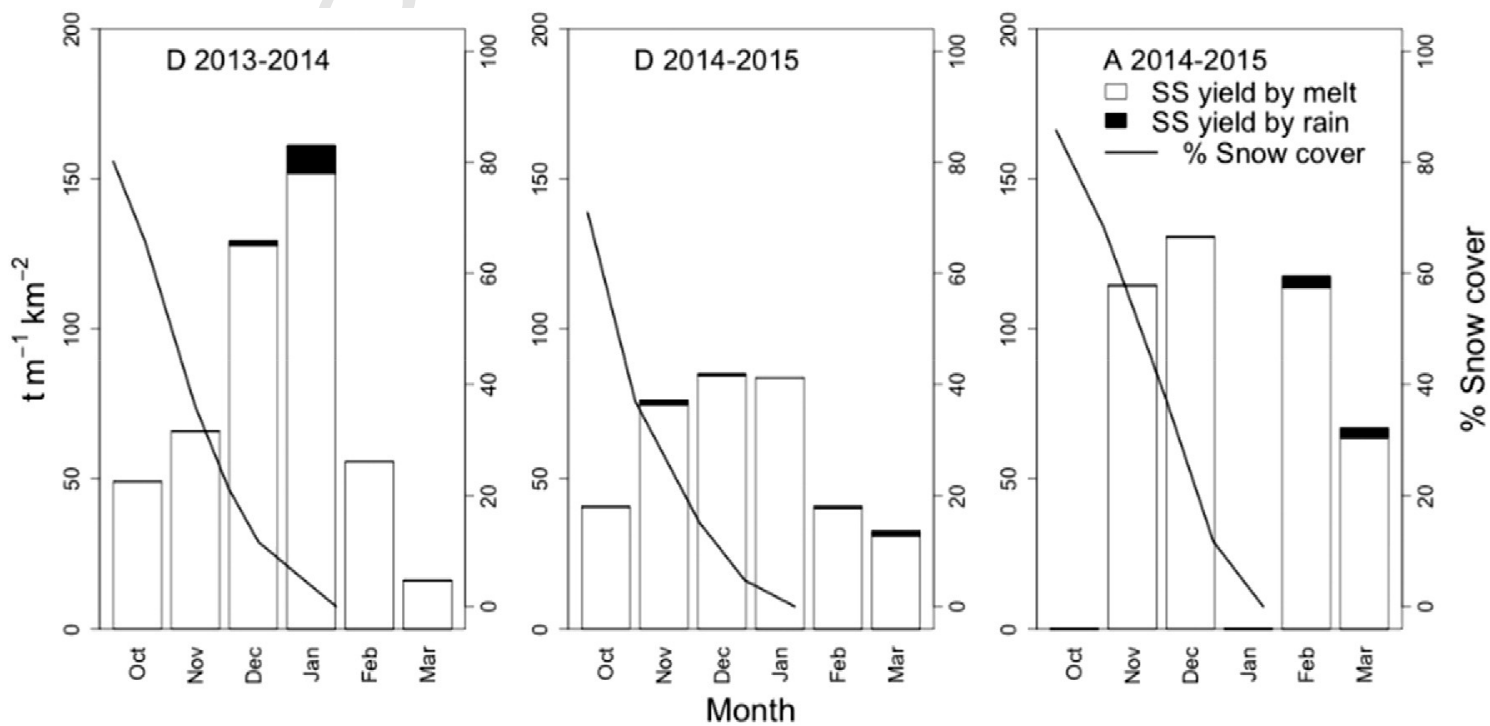

Fig. 5. Monthly sediment yield and percentage of snow cover at the end of each month for the monitoring sites A and D. 

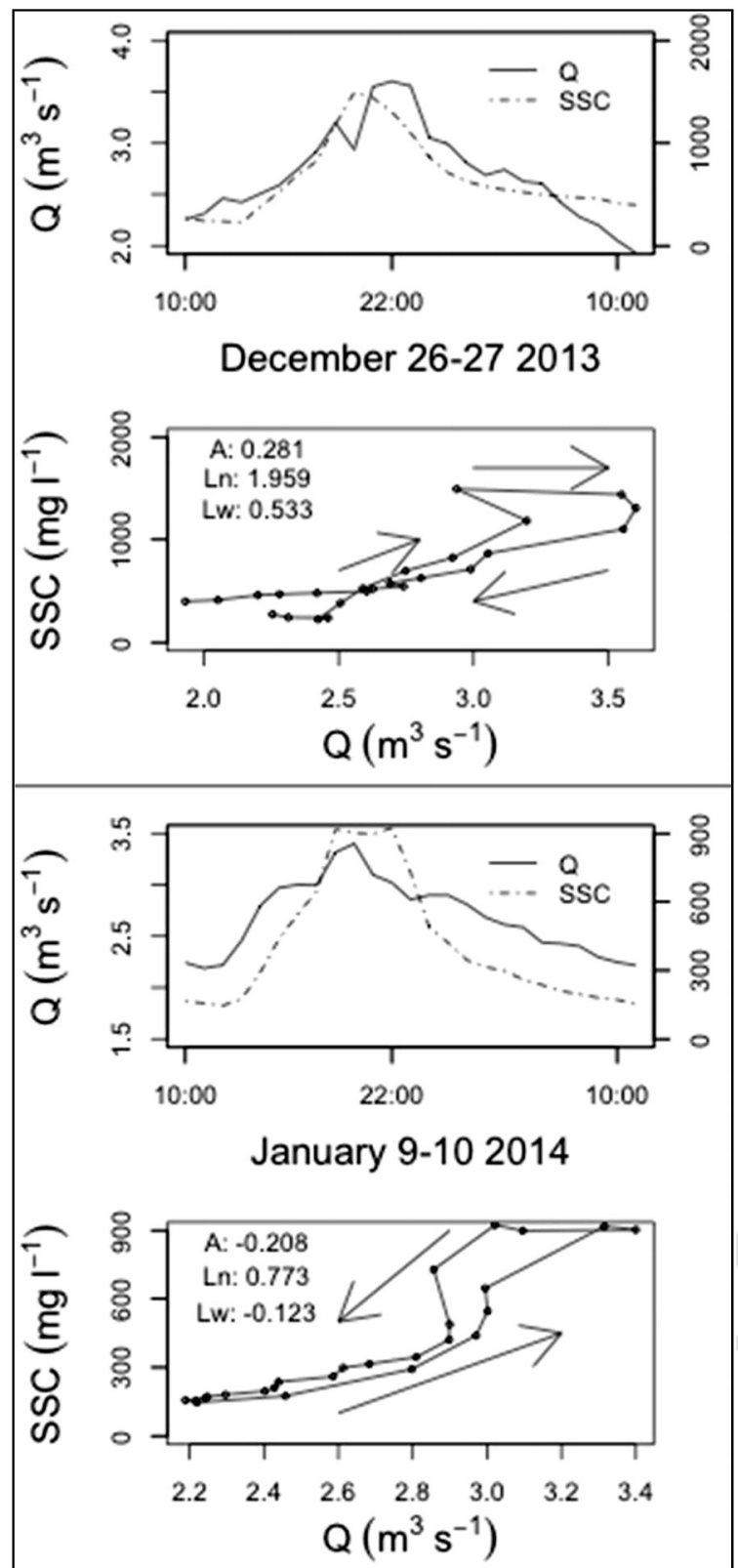

Fig. 6. Daily fluctuations of discharge and suspended sediment transport and hysteresis for two events occurred on the 26-27 December 2013 and 9-10 January 2014 as registered in the monitoring site $\mathrm{D}$.

of $\mathrm{Q}$ and SSC are common on the registered series, the centre of mass of the daily fluctuations of Q and SSC was calculated and their lags between monitoring sites A and D were obtained. Fig. 8 shows the celerity of the center of mass of daily fluctuations of discharge and suspended sediment transport from $A$ to $D$ in terms of velocity. It appears that the propagation of the hydrograph is slower during late glacier melting (February and March) than during late snowmelt and early glacier melting (November and December). This is likely due to the fact that in late February and March the only source of runoff is the glacierized area in the upper part of the basin, and that flood waves are simply routed downstream, at a speed of approximately $1 \mathrm{~m} \mathrm{~s}^{-1}$, which is reasonable considering the slope of the main channel (Fig. 9). Instead, in November and December there is a certain runoff contribution generated by snowmelt and groundwater in the middle and lower portion of the basin, thus anticipating the arrival of the flood wave, and celerity deceptively appears to be higher, up to $10 \mathrm{~m} \mathrm{~s}^{-1}$ (Fig. 9). It is worth noticing that 373 the celerity of the sediment wave appears to be relatively consistent 374 through the seasons, being only slightly higher in November. Indeed, 375 Fig. 8 shows that, irrespective of the celerity of the flood wave, sedi- 376 ments are transferred from A to D at a celerity comparable to the 377 flood waves during glacier melting (around $0.8 \mathrm{~m} \mathrm{~s}^{-1}$ ). This would sug- 378 gest that, apart from the snowmelt period, the main source of fine sed- 379 iments is located above the monitoring site A, and specifically the pro- 380 and peri-glacier area.

\section{Discussions}

382

\subsection{Suspended sediment yield in a glacierized basin of the southern Andes 383}

Calculations of suspended sediment yields from the Andean rivers of 384 Chile are still not abundant in the literature. Pepin et al. (2010) used 385 daily values of SSC and Q to calculate suspended sediment yields from 386 a wide variety of Chilean rivers, showing that values range generally 387 from 0 to $700 \mathrm{t}_{\text {year }}{ }^{-1} \mathrm{~km}^{-2}$. In central Chile, suspended sediment 388 yield is mainly produced in summer. In the proximity of the study 389 basin, Pepin et al. (2010) estimated a yield of around $500 \mathrm{t} \mathrm{year}^{-1} \mathrm{~km}^{-2} 390$ on basins with an area between 1600 and $4800 \mathrm{~km}^{2}$. These values are 391 significantly higher than other basins in central Chile due to the pres- 392 ence of glaciers and the reduced percentage of forest cover. The value 393 of specific suspended sediment yield obtained in the present study is 394 around $470 \mathrm{t}_{\text {year }}{ }^{-1} \mathrm{~km}^{-2}$, which is quite high considering that it was 395 produced during only 6 months. This value is comparable with that re- 396 ported for other glaciers (e.g. $290 \mathrm{t} \mathrm{year}^{-1} \mathrm{~km}^{-2}$, Dunagiri Glacier, 397 Srivastava et al., 2014; 300-1300 t year ${ }^{-1} \mathrm{~km}^{-2}$, Siachen Glacier, 398 Bhutiyani, 2000). Yet, this value is one order of magnitude 399 lower than what reported for other Himalayan and Alpine glaciers 400 (e.g. 4800 t year $^{-1} \mathrm{~km}^{-2}$, Gangotri Glacier, Haritashya et al., 2006; 401 $4500 \mathrm{t} \mathrm{year}^{-1} \mathrm{~km}^{-2}$, Haut Glacier d'Arolla, Hodgkins et al., 1997). 402

In the Estero Morales, approximately half of the suspended sediment 403 yield is due to snowmelt and half to glacier melting. This is due to the 404 high elevation of the study basin and to the Mediterranean type of cli- 405 mate, which lead to the lack of considerable rainfall events in summer- 406 time. This makes the Estero Morales substantially different than other 407 glacierized basins on other latitudes, where typically three periods of 408 sediment yield could be depicted, namely snowmelt, glacier melt and 409 rainfall events, and single rainfall events do not play an important role 410 in activating sediment sources (e.g. Schiefer et al., 2006; Beylich and 411 Kneisel, 2009; Beylich et al., 2010).

4.2. Dynamics of suspended sediment yield and availability in a 413 glacierized basin

Data provided by the Estero Morales show that from early snowmelt 415 to late glacier melting, there is a progressive reduction of suspended 416 sediment concentration for a specific discharge, i.e. progressively higher 417 discharges are needed to transport the same amount of sediments 418 (in $\mathrm{g}^{-1}$ ). This is probably due to the reduced snow cover from the ab- 419 lation area and the progressively limited amount of subglacial sedi- 420 ments. Because the upper part of the glacierized areas are not covered 421 by as much debris as the lower portion of the glacier, it is likely that a 422 textural study could shed light on the relative importance of glacier 423 melting from the upper and lower part of the glacierized area. 424 As showed by Haritashya et al. (2010) among others, the size of 425 transported sediments can reveal the origin of sediments, which is likely 426 to be subglacial from the upper part of the basin and supraglacial from 427 the lower part of the debris-cover glacierized area.

The analysis of suspended sediment transport and hysteresis at the 429 daily scale in the Estero Morales allows inference of the dynamics of 430 sediment availability in a small glacierized basin. Fig. 10 shows a con- 431 ceptual model that helps explain the dynamics of sediment availability 432 and hysteresis in a glacierized basin such as the Estero Morales. 

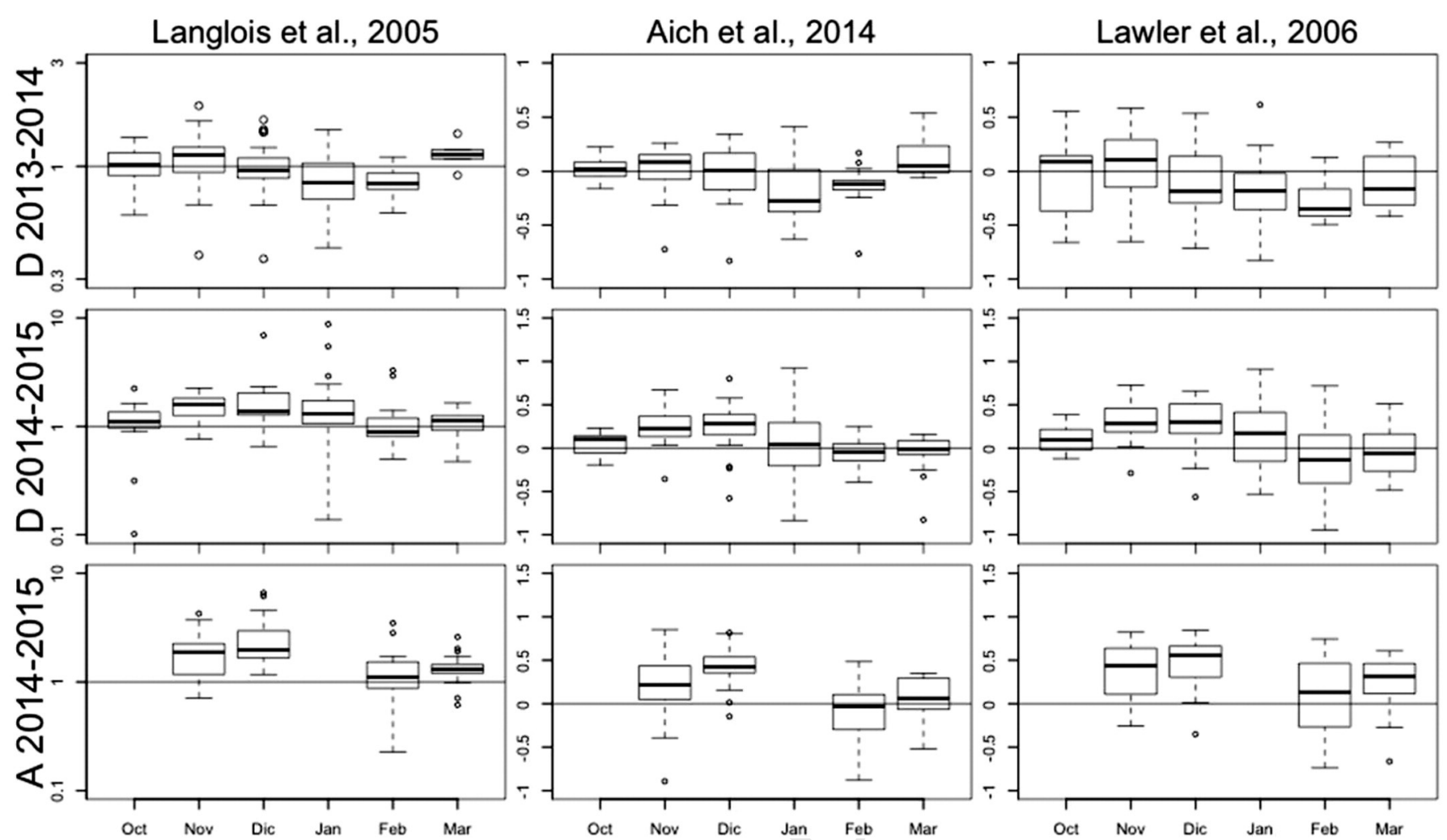

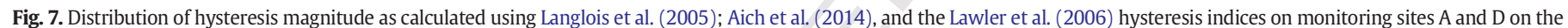
monitoring seasons 2013-2014 and 2014-2015.

At the beginning of the snowmelt season the basin is almost completely covered by snow, and the sources of fine sediments for the first flood events are the slopes and the lower portion of the channel bed. Frozen soils usually limit water infiltration at spring melt, facilitating soil erosion and the delivery of fine sediments to the main stream. The stream channel itself can also represent a source of fine sediment due to bank erosion during the first events (e.g. Nolan and Hill, 1987) and the remobilization of fine sediments from the channel bed. Because 441 sediment sources are ready-available and very close to the monitoring 442 site, hysteresis patterns associated to single events tend to be very 443 weak. However, even if moderate discharges can transport high concen- 444 tration of suspended sediments (see Fig. 4), snowmelt floods are limited 445 in number and magnitude, so that the overall suspended sediment yield 446 is relatively low (see Fig. 5).

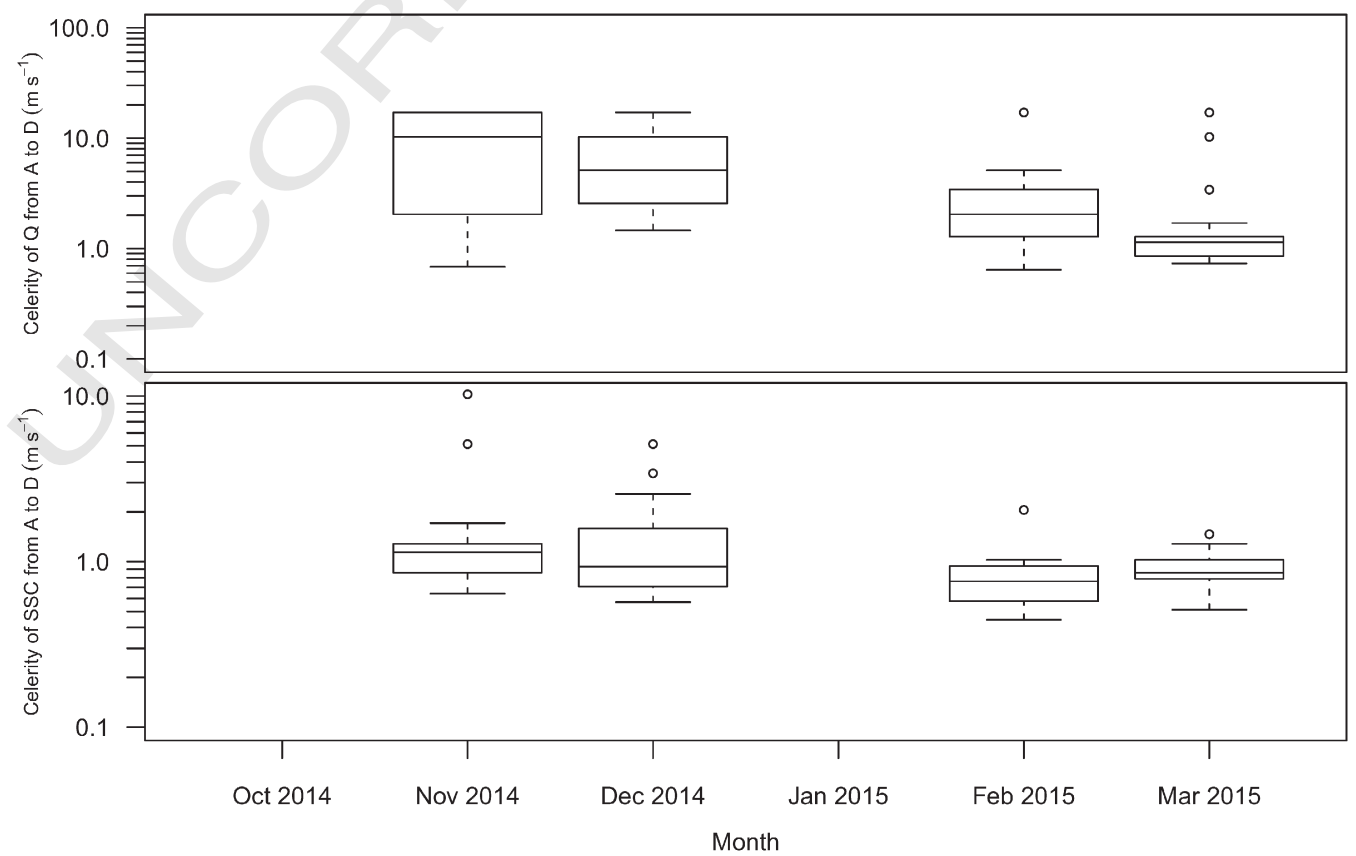

Fig. 8. Celerity of daily fluctuations of discharge (above) and suspended sediment waves (below) propagation from monitoring sites A and D. 

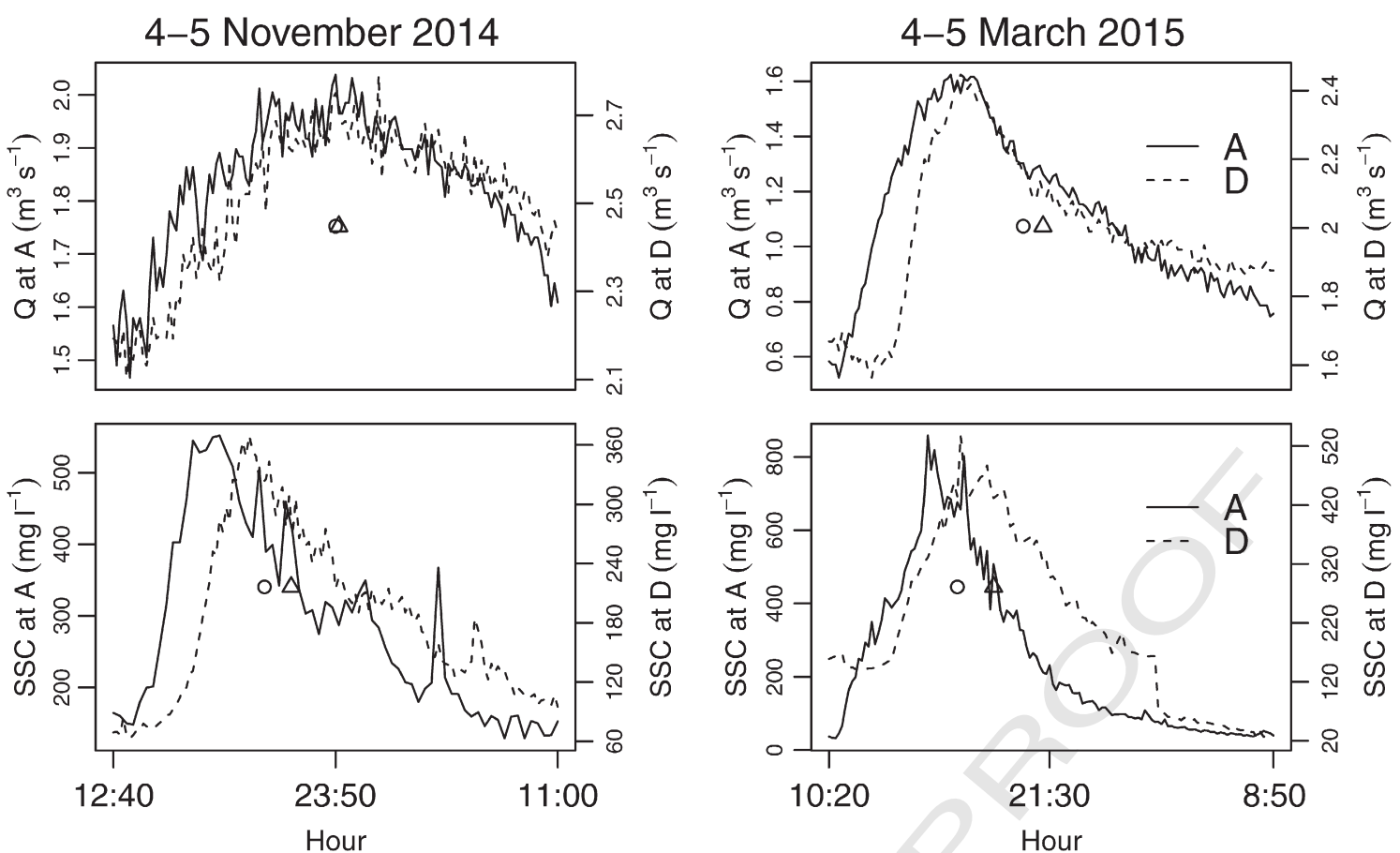

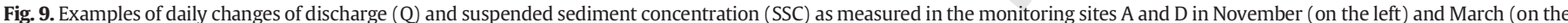

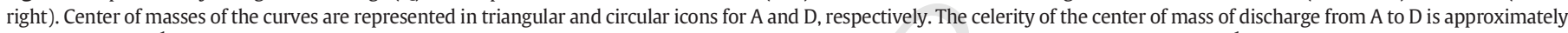

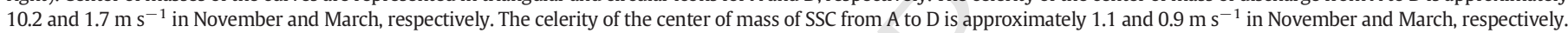

Towards the middle of the snowmelt season (approximately November in the Estero Morales), the hillslopes of the middle part of the basin and the main channel keep furnishing fine sediments, but the proglacial areas starts to be active too, as the glacierized areas begins to melt. Sediment availability is still very high and relatively close to the monitoring point. Owing to the proximity of sediment sources (Asselman, 1999; Gao and Pasternack, 2007) and the probable dilution effect due to the greater contribution of subsurface water to stream flow during the recession stage of the hydrographs (Wood, 1977), the hys- 456 teresis loops of daily floods tend to be clockwise.

During the glacier melt season (approximately from December to 458 February in the Estero Morales), the proglacial area is the main source 459 of sediments transported in suspension by the daily floods. Sediment 460 availability is high during the glacier melting season, which in fact con- 461 tributes the most to the overall sediment yield from the Estero Morales. 462 However, because the main sediment source is far from the monitoring 463

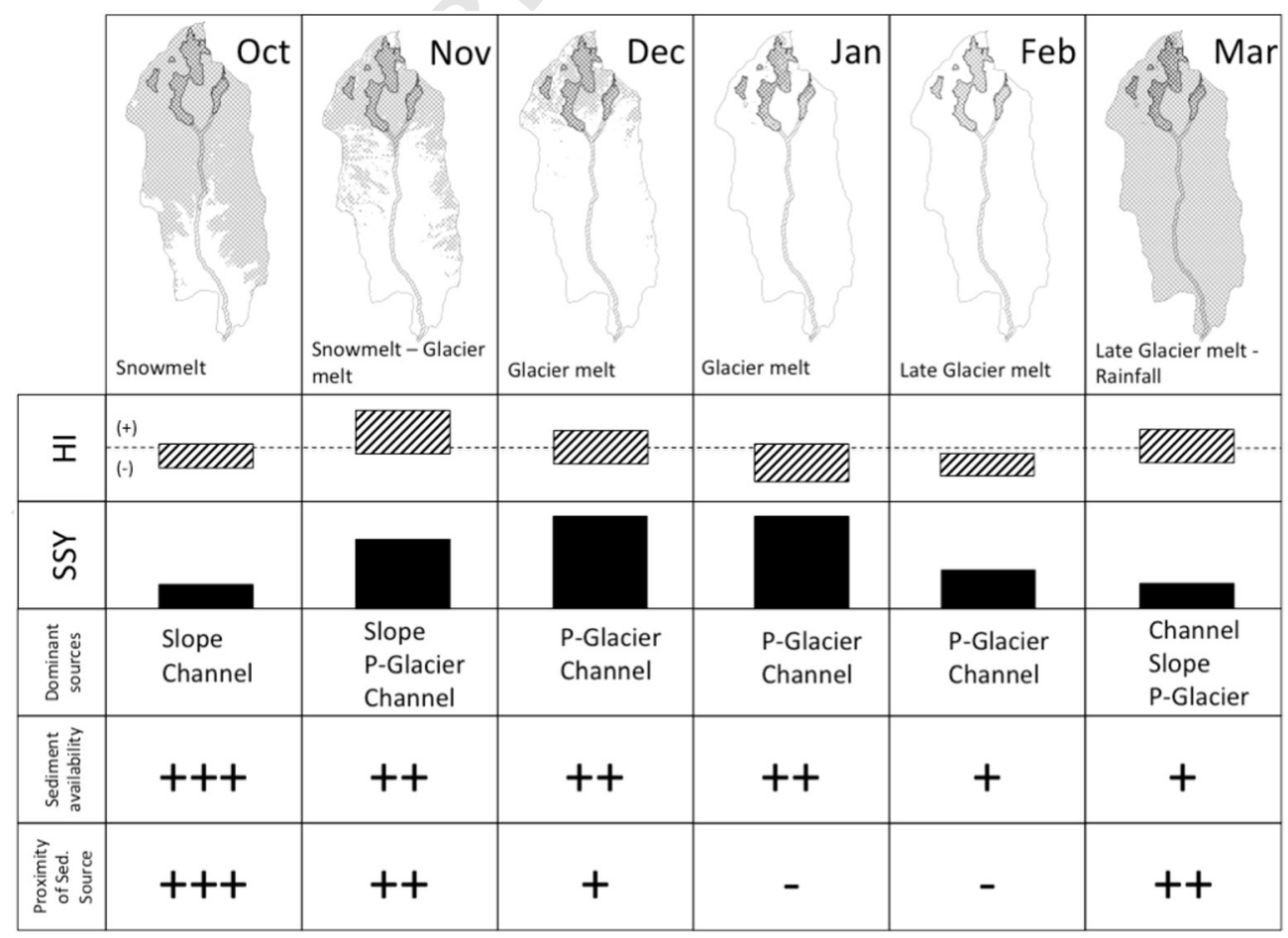

Fig. 10. Conceptual model of the spatial and temporal changes of sediment yield, sources, and predominant hysteresis patterns of daily fluctuations of discharge in the Estero Morales 
site, the hysteresis pattern for daily floods tends to become counterclockwise. This is increasingly more evident towards the end of the glacier melt season, as the groundwater contribution to hydrographs reduces and fine sediment in the main channel becomes depleted. Regarding hysteresis during glacier melting floods, evidence from the literature is somehow contrasting. Singh et al. (2005) analysed hysteresis during melting of the Gangotri glacier in the Himalayas, reporting mostly clockwise hysteresis, whereas in other environments, counterclockwise hysteresis was more common (e.g. Lawler et al., 1992).

At the very end of the glacier melting season and before precipitation begins to fall as snow, the sediment yield is very limited due to the very low magnitude of daily floods and the progressive reduction of sediment availability from the proglacial area. This progressive reduction of suspended sediment concentration and yield towards the end of the melting season has been previously reported and related to limited sediment availability in the subglacial or morainic areas (Østrem, 1975; Collins, 1990; Haritashya et al., 2006). However, because of the first rainfall events that normally occur in this period, hysteresis patterns are not dominated anymore by counterclockwise loops, as during rainfall events the main sediment source is the whole basin and clockwise loops are featured.

Overall, the reduction of suspended sediment transport and tendency from clockwise to counterclockwise hysteresis from early snowmelt to late glacier melt in the Estero Morales has been explained here mainly in terms of depletion of sediments from the subglacial area and ablation front, as previously done in other environments (e.g. Gabet et al., 2008). However, Andermann et al. (2012) showed that groundwater dilution can also help to explain the fate of clockwise hysteresis in glacierized basins. Even if rainfall events are not common and their contribution to suspended sediment yield is negligible in the Estero Morales, it is possible that a progressive recharge of groundwater storage in the basin can be partially claimed to explain the increase of hydrograph celerity from monitoring site A to D during snowmelt (see Fig. 8) and the delay in the arrival of suspended sediments (producing counterclockwise hysteresis). To further explore this possibility, a series of water samples along the 2014-2015 season have been taken at monitoring sites A and D in order to analyse the content of stable isotope of water, which can substantially help in deciphering the main sources (groundwater vs. snowmelt vs. glacier melt) contributing to runoff (e.g. Cable et al., 2011; Penna et al., 2014).

It seems worth stressing here that hysteresis studies generally tend to overlook the fact that the direction and the magnitude of hysteretic patterns are inevitably related to the distance between the likely source of sediments and the monitoring point. Intuitively, the scatter of the relationship between discharge and suspended sediments would increase if the two variables are measured far from the source of runoff and sediments. In the Estero Morales, no significant differences are evident if hysteresis from monitoring points $\mathrm{A}$ and $\mathrm{D}$ is compared. This could be due to the fact that the basin is narrow, with a lack of significant tributaries from $A$ to $D$ that can add complexities to the conveyance of water and sediment waves from A to D, at least when the source of runoff is essentially the glacier (see Fig. 8). Also, the hysteresis pattern is generally already visible in monitoring site $A$, probably due to the fact that the glacierized area in the basin is topographically complex, being divided in several small glacier bodies (some covered by debris and some not), and spanning a wide range of elevations (Fig. 1). In order to shed light on this process of generation and transfer of the hysteretic patterns downstream, multiple monitoring sites would be required along the main channel, and field experience of similar investigations is still not available. Also, it seems worth stressing the importance of monitoring suspended sediment yield over long term scales, as sediment concentration can be very sensitive to snowfall (Iida et al., 2012), climate during the melting seasons (Beylich et al., 2010; Gao and Josefson, 2012), sediment sources at the basis scale (e.g. Mills and Bathurst, 2015), and high-magnitude events (e.g. Schiefer et al., 2010). Long term monitoring programs are needed in order to assess responses to glacier retreat in 530 terms of sediment storage and yield.

\section{Final remarks}

This paper presents a temporal study of suspended sediment yield in 533 a small glacierized basin in the Southern Chilean Andes. Relationships 534 between suspended sediment concentration and discharge, and hyster- 535 etic patterns of daily fluctuations of discharge due to snow and glacier 536 melting are used to infer temporal changes in sediment sources and 537 availability as:

- early snowmelt: fine sediments are provided by the lower part of the 539 basin where snow is melting; sediment availability is almost unlimit- 540 ed and high sediment concentrations are transported by relatively 541 low discharges; hysteresis patterns are not very evident because sed- 542 iment sources are readily-available and very close to the monitoring 543 site;

- late snowmelt and early glacier melting: fine sediments are provided 545 by the middle part of the basin, sediment availability is still very high 546 and high sediment concentrations are transported by relatively low 547 discharges; the main sources are relatively close to the monitoring 548 site and hysteresis patterns tend to be clockwise as the peaks of 549 suspended concentration anticipate the peak of discharges on daily 550 hydrographs;

551

- glacier melting: fine sediments are provided by the proglacial area, far 552 from the monitoring site, making the daily hydrographs feature coun- 553 terclockwise hysteresis with suspended sediment concentration. 554 Higher discharges are necessary to transport a certain concentration 555 of sediments if compared with snowmelt. Because of the higher dis- 556 charges the sediment yield due to glacier melting is very high; and $\quad 557$

- late glacier melting: sediment availability from the proglacial area re- 558 duces progressively, and sediment sources at the basin scale are acti- 559 vated by rainfall events; hysteresis tends to be more counterclockwise 560 if compared with the glacier melting season; sediment yield is very 561 low.

\section{Acknowledgments}

The research was supported by the projects FONDECYT 1130378 and 565 IDRC 107081-001. We are grateful to the Corporación Nacional Forestal 566 (CONAF) for the interest and support in this study. We thank Joaquin 567 Lobato, Juan Pablo del Pedregal, and Riccardo Rainato for their help in 568 the field. Tim Stott and an anonymous reviewer are kindly thanked for 569 their contributions that helped to improve an earlier version of this 570 paper.

\section{References}

Aich, V., Zimmermann, A., Elsenbeer, H., 2014. Quantification and interpretation of 573 suspended-sediment discharge hysteresis patterns: how much data do we need? Ca- 574 tena 122, 120-129. http://dx.doi.org/10.1016/j.catena.2014.06.020.

Andermann, C., Longuevergne, L., Bonnet, S., Crave, A., Davy, P., Gloaguen, R., 2012. Impact 576 of transient groundwater storage on the discharge of Himalayan rivers. Nat. Geosci. 5, 577 127-132. http://dx.doi.org/10.1038/ngeo1356.

Asselman, N.E.M., 1999. Suspended sediment dynamics in a large drainage basin: the 579 River Rhine. Hydrol. Process. 13, 1437-1450.

Beylich, A.A., Kneisel, C., 2009. Sediment budget and relief development in Hrafndalur, 581 subarctic oceanic Eastern Iceland. Arct. Antarct. Alp. Res. 41, 3-17. http://dx.doi.org/ 582 10.1657/1523-0430-41.1.

Beylich, A.A., Liermann, S., Laute, K., 2010. Fluvial transport during thermally and pluvially 584 induced peak runoff events in a glacier-fed mountain catchment in western Norway. 585 Geogr. Ann. A92, 237-246. http://dx.doi.org/10.1111/j.1468-0459.2010.00392.x. $\quad 586$ Bhutiyani, M.R., 2000. Sediment load characteristics of a proglacial stream of Siachen Gla- 587 cier and the erosion rate in Nubra valley in the Karakoram Himalayas. India. J. Hydrol. 588 227, 84-92. http://dx.doi.org/10.1016/S0022-1694(99)00174-2.

Bilotta, G.S., Brazier, R.E., 2008. Understanding the influence of suspended solids on water 590 quality and aquatic biota. Water Res. 42, 2849-2861. http://dx.doi.org/10.1016/j. 591 watres.2008.03.018. 
Blettler, M.C.M., Amsler, M.L., Ezcurra de Drago, I., Espinola, L., Eberle, E., Paira, A., Best, J.L. Parsons, D.R., Drago, E.E., 2015. The impact of significant input of fine sediment on benthic fauna at tributary junctions: a case study of the Bermejo-Paraguay River confluence, Argentina. Ecohydrology 8, 340-352. http://dx.doi.org/10.1002/eco.1511.

Cable, J., Ogle, K., Williams, D., 2011. Contribution of glacier meltwater to streamflow in the Wind River Range, Wyoming, inferred via a Bayesian mixing model applied to isotopic measurements. Hydrol. Process. 25, 2228-2236. http://dx.doi.org/10.1002/ hyp.7982.

Collins, D.N., 1990. Seasonal and annual variations of suspended sediment transport in meltwaters draining from an Alpine glacier. Proceedings of Two Lausanne Symposium, IAHS Publ. no. 193 1990, pp. 439-446.

Collins, L., Zhang, Y.S., Hickinbotham, R., Bailey, G., Darlington, S., Grenfell, S.E., Evans, R., Blackwell, M., 2013. Contemporary fine-grained bed sediment sources across the River Wensum Demonstration Test Catchment, UK. Hydrol. Process. 27, 857-884. http://dx.doi.org/10.1002/hyp.9654.

Curran, J.C., Wilcock, P.R., 2005. Effect of sand supply on transport rates in a gravel-bed channel. J. Hydraul. Eng. 131, 961-967. http://dx.doi.org/10.1061/(ASCE)07339429(2005)131:11(961).

Davis, C.M., Fox, J.F., 2009. Sediment fingerprinting: review of the method and future improvements for allocating nonpoint source pollution. J. Environ. Eng. 135, 490-504. http://dx.doi.org/10.1061/(ASCE)0733-9372(2009)135:7(490).

Duvert, C., Gratiot, N., Evrard, O., Navratil, O., Némery, J., Prat, C., Esteves, M., 2010. Drivers of erosion and suspended sediment transport in three headwater catchments of the Mexican Central Highlands. Geomorphology 123, 243-256. http://dx.doi.org/10. 1016/j.geomorph.2010.07.016.

Fan, X., Shi, C., Shao, W., Zhou, Y., 2013. The suspended sediment dynamics in the InnerMongolia reaches of the upper Yellow River. Catena 109, 72-82. http://dx.doi.org/10. 1016/j.catena.2013.05.010.

Gabet, E.J., Burbank, D.W., Pratt-Sitaula, B., Putkonen, J., Bookhagen, B., 2008. Modern erosion rates in the High Himalayas of Nepal. Earth Planet. Sci. Lett. 267, 482-494. http://dx.doi.org/10.1016/j.epsl.2007.11.059.

Gao, P., Josefson, M., 2012. Event-based suspended sediment dynamics in a central New York watershed. Geomorphology 139-140, 425-437. http://dx.doi.org/10.1016/j. geomorph.2011.11.007.

Gao, P., Pasternack, G., 2007. Dynamics of suspended sediment transport at field-scale drain channels of irrigation-dominated watersheds in the Sonoran desert, southeastern California. Hydrol. Process. 21, 2081-2092. http://dx.doi.org/10.1002/hyp.6398.

Haddadchi, A., Ryder, D.S., Evrard, O., Olley, J., 2013. Sediment fingerprinting in fluvial sys tems: review of tracers, sediment sources and mixing models. Int. J. Sediment Res. 28 560-578. http://dx.doi.org/10.1016/S1001-6279(14)60013-5.

Haritashya, U.K., Singh, P., Kumar, N., Gupta, R.P., 2006. Suspended sediment from the Gangotri Glacier: quantification, variability and associations with discharge and air temperature. J. Hydrol. 321, 116-130. http://dx.doi.org/10.1016/j.jhydrol.2005.07. 037.

Haritashya, U.K., Kumar, A., Singh, P., 2010. Particle size characteristics of suspended sediment transported in meltwater from the Gangotri Glacier, central Himalaya - an indicator of subglacial sediment evacuation. Geomorphology 122, 140-152. http://dx doi.org/10.1016/j.geomorph.2010.06.006.

Hodgkins, R., Tranter, M., Dowdeswell, J., 1997. Solute provenance, transport and denudation in a high Arctic glacierised catchment. Hydrol. Process. 11, 1813-1832.

Iida, T., Kajihara, A., Okubo, H., Okajima, K., 2012. Effect of seasonal snow cover on suspended sediment runoff in a mountainous catchment. J. Hydrol. 428-429, 116-128. http://dx.doi.org/10.1016/j.jhydrol.2012.01.029.

Infante Fabres, N.O., 2009. El monumento natural El Morado. Análisis del Medio Biofísico, Paisaje y Propuesta para Su gestión. Universitat de Barcelona, Spain.

Klein, M., 1984. Anti clockwise hysteresis in suspended sediment concentration during individual storms. Catena 11, 251-257. http://dx.doi.org/10.1016/S0341-8162(84)80024-7.

Langlois, J.L., Johnson, D.W., Mehuys, G.R., 2005. Suspended sediment dynamics associated with snowmelt runoff in a small mountain stream of Lake Tahoe (Nevada). Hydrol. Process. 19, 3569-3580. http://dx.doi.org/10.1002/hyp.5844.

Lawler, D.M., Dolan, M., Tomasson, H., Zophoniasson, S., 1992. Temporal variability of suspended sediment flux from a subarctic glacial river, southern Iceland. In: Bogen, J., Walling, D.E., Day, T.J. (Eds.), Erosion and Sediment Transport Monitoring Programmes in River Basins. IAHS Publication no. 210, Oslo, pp. 233-244.

Lawler, D.M., Petts, G.E., Foster, I.D.L., Harper, S., 2006. Turbidity dynamics during spring storm events in an urban headwater river system: the Upper Tame, West Midlands, UK. Sci. Total Environ. 360, 109-126. http://dx.doi.org/10.1016/j.scitotenv.2005.08. 032

Lenzi, M.A., Marchi, L., 2000. Suspended sediment load during floods in a small stream of the Dolomites (northeastern Italy). Catena 39, 267-282.

Martínez-Carreras, N., Krein, A., Gallart, F., Iffly, J.F., Pfister, L., Hoffmann, L., Owens, P.N. 2010. Assessment of different colour parameters for discriminating potential suspended sediment sources and provenance: a multi-scale study in Luxembourg. Geomorphology 118, 118-129. http://dx.doi.org/10.1016/j.geomorph.2009.12.013.

Masiokas, M.H., Rivera, A., Espizua, L.E., Villalba, R., Delgado, S., Aravena, J.C., 2009. Glacier fluctuations in extratropical South America during the past 1000 years. Palaeogeogr. Palaeoclimatol. Palaeoecol. 281, 242-268. http://dx.doi.org/10.1016/j.palaeo.2009.08. 006.

Mills, C.F., Bathurst, J.C., 2015. Spatial variability of suspended sediment yield in a gravelbed river across four orders of magnitude of catchment area. Catena 133, 14-24 http://dx.doi.org/10.1016/j.catena.2015.04.008.
Montgomery, D.R., Buffington, J.M., 1997. Channel-reach morphology in mountain drain- 674 age basins. Geol. Soc. Am. Bull. 109, 596-611.

Moore, R.D., 2005. Slug injection using salt in solution. Streamline Watershed Manag. 8, 676 1-6. http://dx.doi.org/10.1592/phco.23.9.1S.32890.

Motha, JA, Wallbrink, PJ Hairsine, P.B., Grayson, R.B., 2003. Determining the sources of 678 suspended sediment in a forested catchment in southeastern Australia. Water 679 Resour. Res. 39, 1056. http://dx.doi.org/10.1029/2001WR000794.

Nolan, K.M. Hill, B.R., 1987. Sediment budget and storm effects in a drainage basin tribu- 681 tary to Lake Tahoe. Eos 68, 305.

Østrem, G., 1975. Sediment transport in glacial melt water streams. In: Jopling, A.V., 683 McDonald, B.C. (Eds.), Glaciofluvial and Glaciolacustrine Sedimentation, Society of 684 Economic Paleontologists and Mineralogists. vol. 23, pp. 101-122 Special Publication. 685

Owens, P.N., Batalla, R.J., Collins, A.J., Gomez, B., Hicks, D.M., Horowitz, A.J., Kondolf, G.M., 686 Marden, M., Page, M.J., Peacock, D.H., Petticrew, E.L., Salomons, W., Trustrum, N.A., 687 2005. Fine-grained sediment in river systems: environmental significance and man- 688 agement issues. River Res. Appl. 21, 693-717. http://dx.doi.org/10.1002/rra.878. 689

Pellicciotti, F., Ragettli, S., Carenzo, M., McPhee, J., 2014. Changes of glaciers in the Andes 690 of Chile and priorities for future work. Sci. Total Environ. 493, 1197-1210. http://dx. 691 doi.org/10.1016/i.scitotenv.2013.10.055.

Penna, D., Engel, M., Mao, L., Dell'Agnese, a., Bertoldi, G., Comiti, F., 2014. Tracer-based 693 analysis of spatial and temporal variation of water sources in a glacierized catchment. 694 Hydrol. Earth Syst. Sci. Discuss. 11, 4879-4924. http://dx.doi.org/10.5194/hessd-11- 695 4879-2014.

Pepin, E., Carretier, S., Guyot, J.L., Escobar, F., 2010. Specific suspended sediment yields of 697 the Andean rivers of Chile and their relationship to climate, slope and vegetation. 698 Hydrol. Sci. J. 55, 1190-1205. http://dx.doi.org/10.1080/02626667.2010.512868. 699

Rinaldi, M., Casagli, N., Dapporto, S., Gargini, A., 2004. Monitoring and modelling of pore 700 water pressure changes and riverbank stability during flow events. Earth Surf. 701 Process. Landf. 29, 237-254. http://dx.doi.org/10.1002/esp.1042. 702

Rivera, A., Casassa, G., Acuña, C., Lange, H., 2000. Variaciones recientes de glaciares en 703 Chile. Invest. Geogr. Chile 34, 29-60.

Rovira, A., Batalla, R.J., 2006. Temporal distribution of suspended sediment transport in a 705 Mediterranean basin: The Lower Tordera (NE SPAIN). Geomorphology 79, 58-71. 706 http://dx.doi.org/10.1016/j.geomorph.2005.09.016.

Ryan, P., 1991. Environmental effects of sediment on New Zealand streams: a review. N. Z. 708 J. Mar. Freshw. Res. 25, 207-221. http://dx.doi.org/10.1080/00288330.1991.9516472. 709

Schiefer, E., Menounos, B., Slaymaker, O., 2006. Extreme sediment delivery events record- 710 ed in the contemporary sediment record of a montane lake, southern Coast Moun- 711 tains, British Columbia. Can. J. Earth Sci. http://dx.doi.org/10.1139/e06-056. 712

Schiefer, E., Hassan, M., Menounos, B., Pelpola, C.P., Slaymaker, O., 2010. Interdecadal pat- 713 terns of total sediment yield from a montane catchment, southern Coast Mountains, 714 British Columbia, Canada. Geomorphology 118, 207-212. http://dx.doi.org/10.1016/j. 715 geomorph.2010.01.001.

Singh, P., Haritashya, U.K., Ramasastri, K.S., Kumar, N., 2005. Diurnal variations in 717 discharge and suspended sediment concentration, including runoff-delaying charac- 718 teristics, of the Gangotri Glacier in the Garhwal Himalayas. Hydrol. Process. 19, 719 1445-1457. http://dx.doi.org/10.1002/hyp.5583. iment in meltwater from Glaciers of Garhwal Himalaya. Hydrol. Process. 28, 969-979. 722
721 http://dx.doi.org/10.1002/hyp.9631.

Stott $T$, Nuttall, A.-M., Biggs, E., 20 ics from a minor glacierized basin in south-west Greenland. Geogr. Tidsskr. J. Geogr. 725 114, 1-16. http://dx.doi.org/10.1080/00167223.2013.862911.

Walling DE, Amos, CM. 1999. Source, storage and mobilisation of fine sediment in a 726 chalk stream system. Hydrol. Process. 13, 323-340. http://dx.doi.org/10.1002/ 728 (SICI)1099-1085(19990228)13:3<323::AID-HYP741>3.0.CO;2-K.

Walling D.E. Webb, B.W. 1982. Sediment availability and the prediction of storm-period 730 sediment yields. Recent Dev. Explan. Predict. Eros. Sediment Yield (Proceedings Exet. 731 Symp.). 137, pp. 327-337.

Walling, D.E., Collins, A.L., Jones, P.A., Leeks, G.J.L., Old, G., 2006. Establishing fine-grained 733 sediment budgets for the Pang and Lambourn LOCAR catchments, UK. J. Hydrol. 330, 734 126-141. http://dx.doi.org/10.1016/j.jhydrol.2006.04.015. 735

Wilber, D.H., Clarke, D.G., 2001. Biological effects of suspended sediments: a review of 736 suspended sediment impacts on fish and shellfish with relation to dredging activities 737 in estuaries. N. Am. J. Fish Manag. 21, 855-875. http://dx.doi.org/10.1577/1548- 738 8675(2001)0212.0.CO

Williams, G., 1989. Sediment concentration versus water discharge during single hydro- 740 logic events in rivers. J Hydrol 111,89-106.

Wood, P.A., 1977. Controls of variation in suspended sediment concentration in the River 742 Rother, West Sussex, England. Sedimentology 24, 437-445. 743

Wood, P.J., Armitage, P.D., 1999. Sediment deposition in a small lowland stream - man- 744 agement implications. Regul. Rivers Res. Manag. 15, 199-210. 745

Wulf, H., Bookhagen, B., Scherler, D., 2012. Climatic and geologic controls on suspended 746 sediment flux in the Sutlej River Valley, western Himalaya. Hydrol. Earth Syst. Sci. 747 16, 2193-2217. http://dx.doi.org/10.5194/hess-16-2193-2012. 748

Yeshaneh, E., Eder, A., Blöschl, G., 2013. Temporal variation of suspended sediment trans- 749 port in the Koga catchment, North Western Ethiopia and environmental implications. 750 Hydrol. Process. 5984, 5972-5984. http://dx.doi.org/10.1002/hyp.10090. 